\title{
Speciation of technologically critical elements in the environment using chromatography with element and molecule specific detection
}

\author{
Justyna Wojcieszek a, b , Joanna Szpunar ${ }^{\text {a, * }}$, Ryszard Lobinski ${ }^{\text {a, b }}$ \\ ${ }^{a}$ CNRS/UPPA, Institute of Analytical Sciences and Physical Chemistry for the Environment and Materials (IPREM), UMR 5254, Hélioparc, 2, Av. Pr. Angot, \\ 64053 Pau, France \\ ${ }^{\mathrm{b}}$ Chair of Analytical Chemistry, Faculty of Chemistry, Warsaw University of Technology, Noakowskiego 3, 00-664 Warsaw, Poland
}

\section{A R T I C L E I N F O}

\section{Article history:}

Available online $\mathrm{xxx}$

\section{Keywords:}

Coupled techniques

REE

PGE

Thallium

Tellurium

Germanium

\begin{abstract}
A B S T R A C T
The growing release of technology-critical elements (TCEs): Ga, Ge, In, Nb, Ta, Te, Tl, and most of the platinum group elements (PGEs), and rare earth elements (REEs) requires the understanding of their mobility, reactivity and chemical transformations in the environment which are critically dependent on their chemical form (speciation). The total concentrations of these elements at the trace levels make their speciation analysis challenging. Coupled techniques combining a high resolution chromatographic separation with ultrasensitive element-specific detection by inductively coupled plasma mass spectrometry (ICP MS) often offer the unique possibility of accessing the information on the identities and concentrations of individual metal species present in environmental samples. This paper reviews the advantages and limitations of these techniques to TCEs speciation and highlights the development trends in analytical methodology that may contribute to our understanding of the risks associated with the increasing environmental presence of TCEs.
\end{abstract}

(c) 2017 Elsevier B.V. All rights reserved.

\section{Introduction}

The development of novel technologies, especially in the areas of consumer electronics, renewable energies and health care, has resulted in bringing to the public awareness several elements of

Abbreviations: AAS, electrothermal atomic absorption; AEC, anion exchange chromatography; AFS, atomic fluorescence spectroscopy; BOPTA, benzyloxypropionictetraacetate; BT-DO3A，2-[4,7-bis(2-oxido-2-oxoethyl)-10-(1,3,4trihydroxybutan-2-yl)-1,4,7,10-tetraazacyclododec-1-yl] acetate; CRM, Certified Reference Material; CZE, capillary zone electrophoresis; DOTA, 1,4,7,10tetraazacyclododecane-1,4,7,10-tetraacetic acid; DTPA, pentacarboxymethyldiethylenetriamine; EDTA, ethylenediaminetetraacetic acid; GC, gas chromatography; HILIC, hydrophilic ion interaction liquid chromatography; HPLC, high performance liquid chromatography; IC, ion chromatography; ICP AES, inductively coupled plasma atomic emission spectrometry; ICP MS, inductively coupled plasma mass spectrometry; LA, laser ablation; LC, liquid chromatography; LOD, limit of detection; LOQ limit of quantification; MIP AES, microwave induced plasma atomic emission spectrometry; MRI, magnetic resonance imaging; MS, mass spectrometry; PGEs, platinum group elements; RREs, rare earth elements; RSD, relative standard deviation; SF ICP MS, sector field inductively coupled plasma mass spectrometry; SPE, solid phase extraction; TCEs, technology-critical elements; US EPA, United States Environmental Protection Agency; XANES, X-ray absorption near edge structure.

* Corresponding author. CNRS/UPPA, UMR 5254, Pau, France.

E-mail address: joanna.szpunar@univ-pau.fr (J. Szpunar). which the existence had been considered as a simple curiosity. These elements, referred to as technology-critical elements (TCEs), include $\mathrm{Ga}$, In, Ge, Te, $\mathrm{Nb}$ and $\mathrm{Ta}, \mathrm{Tl}$, the platinum group elements (Ir, Os, Pd, Pt, Rh and Ru), and most of the rare earth elements (Ce, Dy, Er, Eu, Gd, Ho, La, Lu, Nd, Pr, Sm, Tb, Y, Yb). Despite the relatively low occurrence in the earth crust, the development of the technologies of their mining and enrichment has resulted in a number of cases of considerable local release [1-4]. This is gradually contributing to the increasing diffuse pollution, especially in industrially developed areas, raising concerns about the chronic toxicity of the TCEs to the aquatic environment and man [5-8].

The mobility, reactivity and chemical transformations of metals and metalloids in the environment are critically dependent on their chemical form (speciation) [9]. The access to the speciation information requires analytical techniques which produce a signal characteristic not of the total element but of a specific species allowing its detection, confirmation of its identity or non-targeted identification, and quantification. The initial approaches (which are nota bene still widely used) are based on a chemical reaction characteristic to a given species [such as, e.g. hydride generation of As(III)] allowing their specific isolation from the sample matrix prior to determination by atomic spectrometry, electrothermal atomic absorption (AAS), fluorescence (AFS), inductively coupled plasma atomic emission (ICP AES) or mass spectrometry (ICP MS). 
The species are defined by their reactivity and their identity is deduced from this reactivity. Alternatively, the species can be probed directly in a solid sample, by e.g., X-ray Absorption Spectroscopy which, despite its poor sensitivity, may be useful for highly contaminated samples and presents an advantage of being able to study solid samples without (potentially risky in terms of species stability) leaching/extraction sample preparation step. Alternative techniques for liquid samples (or sample extracts) include, e.g., electrochemistry and electrospray MS $[9,10]$.

The ultimate resolution and sensitivity are offered by coupled (hyphenated) techniques which combine a separation by chromatography or electrophoresis with elemental or molecular MS detection [11,12]. Coupled techniques such as gas chromatography with AAS, microwave induced plasma AES and ICP MS have led to considerable advances of our understanding of organomercury, organolead and organotin contamination. They also allowed the description of the multitude of arsenic transformation pathways in the environment $[13,14]$. In biological samples these techniques made possible a rapid in vivo species selective analysis shedding light on the metabolomics and proteomics of metals in plants and higher organisms, referred to as metallomics [10,15]. Whereas ICP MS is still the most widely used detector, the rapid progress in electrospray MS in terms of resolution and sensitivity is offering new opportunities, especially in terms of non-targeted metal-species identification.

The data on the speciation of TCEs in the literature are relatively scarce and essentially limited to Ge, Te, Tl, Pt, Pd, Rh, and Gd (Fig. 1). The purpose of this review is to address the challenges and opportunities offered by coupled techniques to describe, on the molecular level, the speciation of TCEs in different environmental compartments: waste waters, fresh and seawater, aquatic biota and plants. The currently available procedures for the determination of TCE species, especially those with known or suspected deleterious effects, are critically evaluated.

\section{Technologically critical elements and their species}

The species of interest for the different TCEs addressed by the coupled techniques are summarised in Fig. 2.

\subsection{Gadolinium}

The main source of the environmental input of $\mathrm{Gd}$ is due to the use of Gd-based contrast agents for magnetic resonance imaging [16]. The contrast agents are either macrocyclic complexes or linear (open chain) complexes shown in Fig. 2 [17]. They are thermodynamically highly stable, highly polar and highly soluble in water. The majority of them are not removed during the waste water treatment and find their way up seawater $[18,19]$ and drinking water [20]. The contrast agent compounds are bioavailable and can be transported from roots to leaves [21]. Although the chronic effects of such pollution are unknown, the low toxicity of the species is unlikely them to produce a danger to human health at the concentration levels encountered, unless more toxic degradation products are produced (e.g., free $\mathrm{Gd}^{3+}$ is highly toxic because of a similar ionic radius as $\mathrm{Ca}$ ). Whereas some compounds (e.g. Gd-DTPA, Gd-DOTA, Gd-BT-DO3A) are generally stable towards UV radiation, the degradation of others, e.g., Gd-BOPTA was observed in model laboratory experiments. The applied UV irradiation conditions cannot be considered to be an accurate simulation of environmental conditions, however, it is necessary to conduct further studies to evaluate the toxicity of Gd-containing degradation products [20].

\subsection{Other rare earth elements}

In addition to the specific application of Gd in MRI, emissions of all of the REEs to the environment have increased because of their use in functional materials, catalysts, and fertilizers, especially in China [22]. REEs are not considered as essential but beneficial effects on plants were reported [23]Toxic effects, largely due to the similarity in terms of ionic radius with calcium in bacteria, plants and animals were reported [24]. REEs in the environment have the affinity to humic complexes and their behaviour in this respect was extensively investigated in model laboratory experiments [25-28].

\subsection{Thallium}

Thallium is released into the environment from sulphide ores during their processing and smelting, in addition to fossil fuel

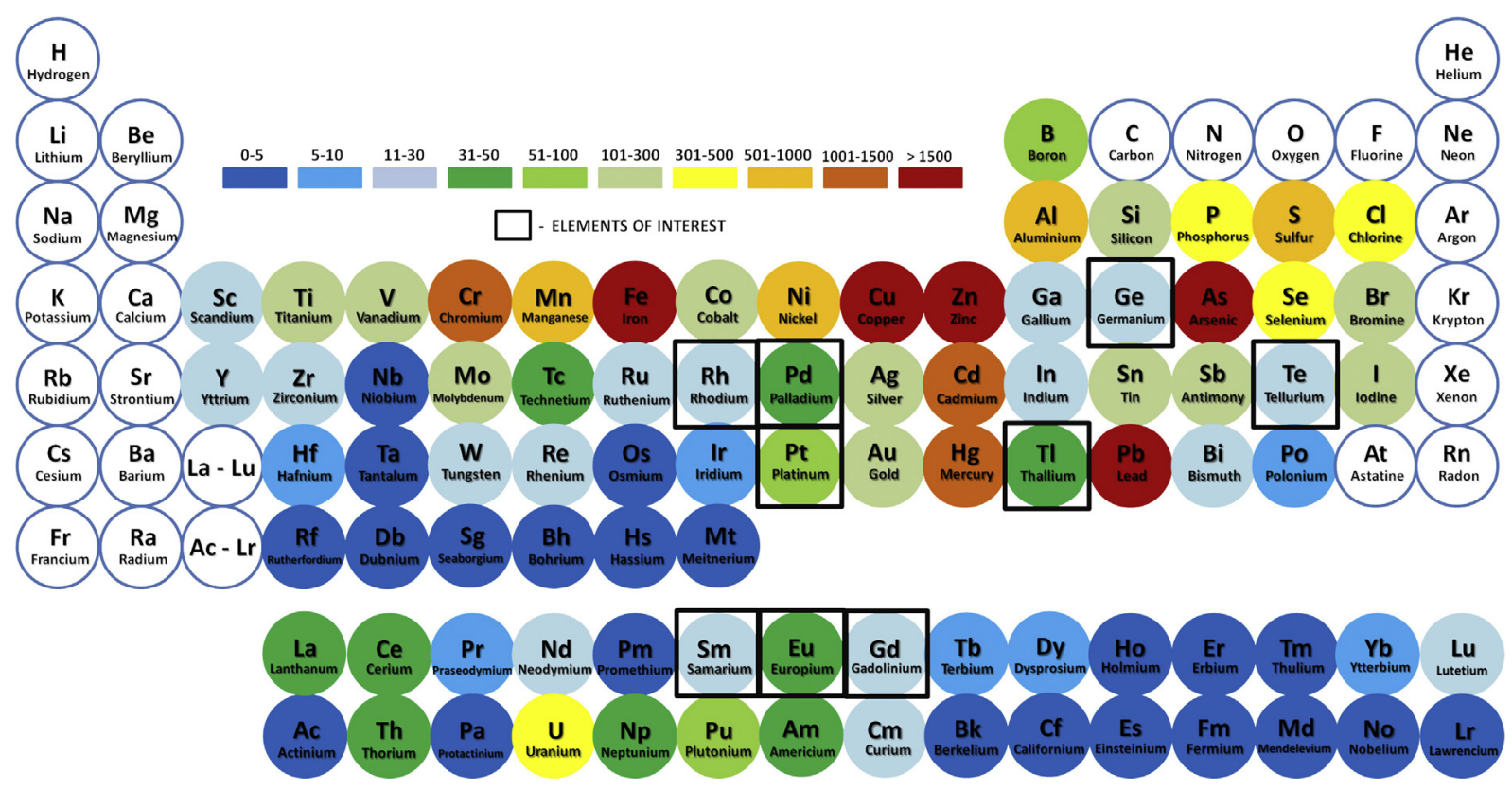

Fig. 1. Number of publications per technological essential element using a keyword "speciation" in the context of other elements (Scopus). 

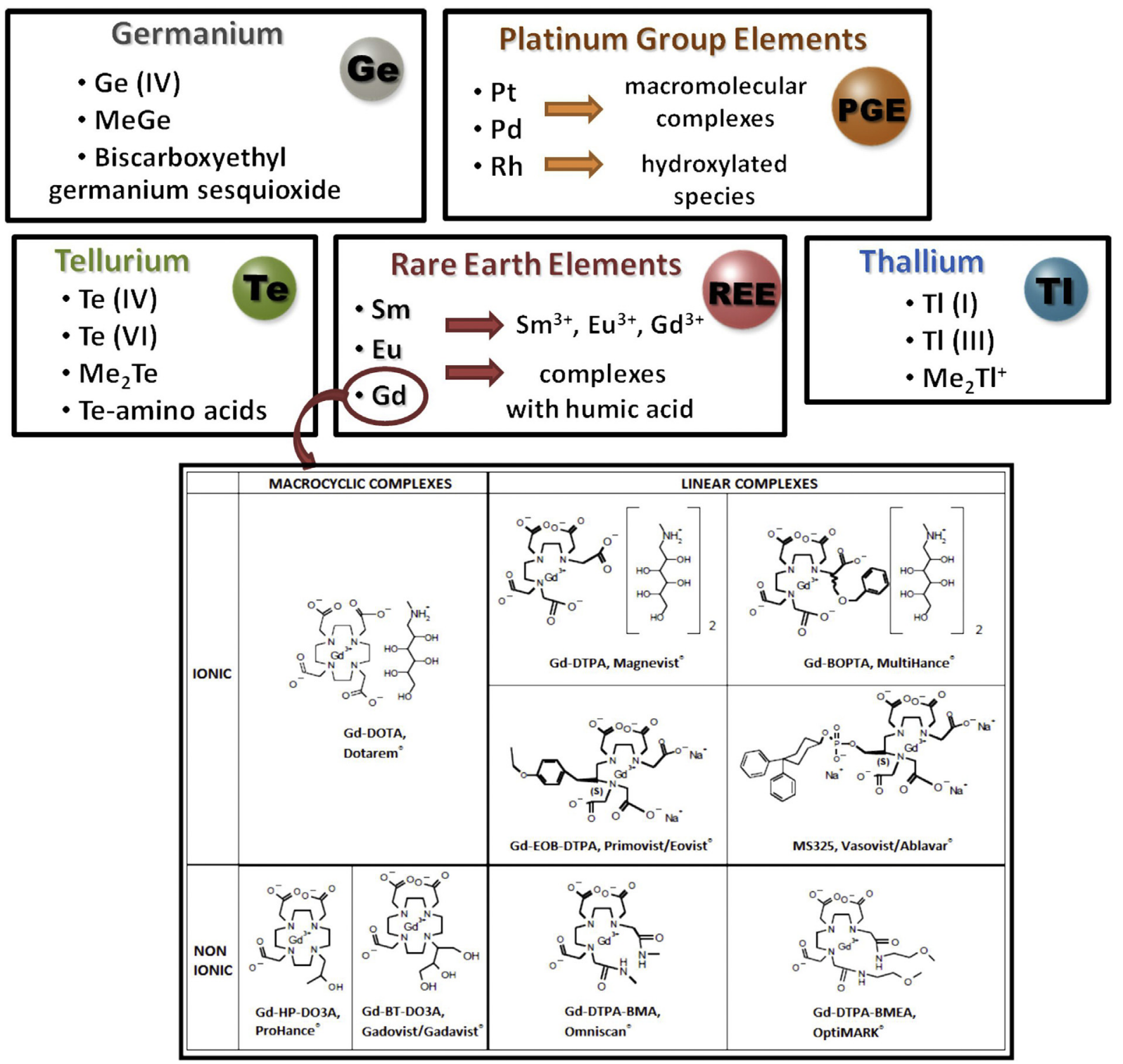

Fig. 2. Species of interest addressed by coupled techniques for the technologically critical elements [17].

combustion. The steady increase in this type of activities results in the continual increase in $\mathrm{Tl}$ concentrations in the environment [29-31]. Thallium is listed by US EPA as a priority pollutant [32]. The toxicity and environmental mobility of Tl are critically dependent on the oxidation state. The toxicity of $\mathrm{Tl}(\mathrm{I})$ is 100 times higher than that of $\mathrm{Cd}$ and the literature available is only a tiny fraction in comparison with that on Cd. Moreover, there is evidence that $\mathrm{Tl}(\mathrm{I})$ can be metabolised to $\mathrm{Tl}$ (III) by plankton [33] which is 50,000 times more toxic that $\mathrm{Tl}(\mathrm{I})$. The acute toxicity of $\mathrm{Tl}(\mathrm{III})$ to mammals is greater than that of $\mathrm{Hg}(\mathrm{II}), \mathrm{Cd}(\mathrm{II})$ and $\mathrm{Pb}(\mathrm{II})$. Tl(III) is reported to be more abundant species in sea and lake waters $[31,34,35]$ whereas $\mathrm{Tl}(\mathrm{I})$ (analogue of potassium) occurs predominantly on soil and roots, stems and leaves of plants [36,37]. $\mathrm{Me}_{2} \mathrm{Tl}^{+}$was detected in fresh water [38] and accounts for up to $50 \%$ of $\mathrm{Tl}$ in the ocean [39]. The conversion of $\mathrm{Tl}$ to methylated forms is of significant importance because of its toxicity, on one hand, and of the environmental mobility on the other hand [39].

\subsection{Platinum group elements}

Platinum group elements concentrations have been increasingly detected in the environment since mid-1980 [40]. The main sources of PGEs are (i) the abrasion of Pt, Pd and Rh from vehicle exhausts car catalysts [41-43], and (ii) the use of Pt drugs, mostly cisplatin in cancer therapy $[44,45]$. The automobile pollution results in the measured concentrations of up to several $\mu \mathrm{g} / \mathrm{g}$ in road dust $[6,46,47]$. The concentrations reported for the Road Dust CRM 723 collected in a tunnel: $80 \mu \mathrm{g} / \mathrm{g} \mathrm{Pt}, 13 \mu \mathrm{g} / \mathrm{g}$ Rh and $6 \mu \mathrm{g} / \mathrm{g}$ Pd illustrate well the proportion between the concentrations of the different PGE elements. Although PGEs are considered to be inert, those contained in road dust can actually be solubilized and enter the waters, sediments, soil and finally the food chain. The speciation studies suggest that Pt forms can be metabolized by plants and transported to leaves $[48,49]$. The potential presence of soluble Pt species may raise health concerns as they are potent allergens and 
sensitizers, associated with a number of diseases [6]. However, the low concentrations involved limit the risk to cases of prolonged exposure and chronic toxicity. The release of Pt due to its use in metallodrugs is confined and locally limited to hospital effluents and waste waters. The released total $\mathrm{Pt}$ concentrations vary considerably; values of up to $250 \mathrm{ng} / \mathrm{mL}$ in waste water were reported [45].

\subsection{Tellurium}

Tellurium is increasingly employed in the production of optical magnetic discs, solar panels and Peltier devices. Effluents from metallurgical industries may contain up to $3 \mathrm{mg} / \mathrm{L}$ of Te [50]. The toxicity depends on the species: Te(IV) is an order of magnitude more toxic than $\mathrm{Te}(\mathrm{VI})$. Tellurium (VI) is less thermodynamically stable but more abundant than Te(IV). Tellurium in environments of high microbial activity may undergo biomethylation [51] and the methylated product shows distinctly different mobility, bioavailability and toxicity. Plants, such as Indian mustard, broccoli or garlic tend to accumulate tellurium leading to a risk of Te exposure by ingestion through the food web. Garlic was shown to be able to convert tellurium into telluroamino acid [52].

\subsection{Germanium}

Germanium is increasingly used in semiconductor, optical and telecommunication industries [53]. Organic germanium compounds, especially, beta-carboxyethylgermanium [54] and bisbeta-carboxyl germanium sesquioxide, enjoy interest for the health care and anticancer activity [55]. Germanium released in the environment can readily undergo microbial assisted methylation [56]. Germanium is not essential for humans and in general its toxicity is low [57] but acute and chronic toxic effects of $\mathrm{GeO}_{2}$ accumulating in kidney have been demonstrated [58].

\section{Coupled techniques: state-of the art}

The two main types of hyphenated techniques are shown in Fig. 3. ICP MS is the principal detector because of its high sensitivity, multi-element and multi-isotope capability in view of isotope ratio determination and isotope dilution analysis and the virtual independence on the signal on the species in which element is present. The latter feature allows to avoid false positives (common in AAS) and false negatives (common in electrospray MS). It also allows the follow-up and control of the mass balance of the target element during analysis. In its standard form the technique is based on the conversion of a liquid samples into an aerosol which is introduced into an inductively coupled plasma where elements are atomized and ionized in the high temperature. The ions are separated according to their $m / z$ ratio and detected. Quadrupole instruments are commonly used; the introduction of collision cells allowed the control of the interferences and reduced the detection limits. The ultimate sensitivity is achieved using sector field instruments used in a low resolution $(\mathrm{R}=300)$ mode. For custom designed applications the use of triple quadrupole detection may be advised [59].

The species selectivity of ICP MS is achieved by a coupling to a separation technique, usually chromatography; its choice depends on the physicochemical properties of the species of interest. Gas chromatography following purge-and-trap sample introduction is used for the volatile species such as methylated forms of elements [60]. HPLC using different separation mechanisms is used for the quantitative determination of species of interest and cartography of species of interest [61]. Electrospray MS detection is necessary for the identification of the metabolism products or molecular targets in biological systems [62]. Therefore, HPLC with the parallel ICP MS and electrospray MS detection is recommended for the exploratory studies and identification of novel metallomolecules in biological systems $[63,64]$.

\section{1. $G C-I C P M S$}

A typical setup is shown in Fig. 3a [60]. The method originally developed for the mercury species [65], consists of purging the volatile species from a large volume of aqueous solution with nitrogen, elimination of the water using a low temperature $\left(-20^{\circ} \mathrm{C}\right)$ or a Nafion membrane dryer, cryotrapping of the species of interest at $-196^{\circ} \mathrm{C}$, and their thermal release into a chromatographic packed or capillary column. In this way, fully methylated species such as $\mathrm{Me}_{2} \mathrm{Te}$ or $\mathrm{Me}_{4} \mathrm{Ge}$ can be determined. The addition of $\mathrm{NaBH}_{4}$ or $\mathrm{NaBEt}_{4}$ allows non-completely methylated species, such as e.g., $\mathrm{MeTe}^{+}$or $\mathrm{MeGe}^{3+}, \mathrm{Me}_{2} \mathrm{Ge}^{2+}$ or $\mathrm{Me}_{3} \mathrm{Ge}^{+}$to be derivatized to produce hydrides (or ethylated derivatives, respectively) that are then separated by GC. The use of the method demands a skilled operator to reach very low detection limits. For simple applications, the same chemistry and commercially available purge and trap injectors can be applied.

\subsection{HPLC-ICP MS}

The interface, schematically shown in Fig. 3b has become straightforward with the availability of commercial nebulisers and spray chambers available for any flow rate and hence, the column diameter. The problems reported in early publications with the plasma instability due to the high concentrations of the organic modifiers (methanol or acetonitrile) have been solved in modern instruments [66]. Nevertheless, there are some limitations regarding the type (preferably formate, acetate or carbonate) of buffer used and concentrations (up to $10-50 \mathrm{mM}$ ) of the buffer used which may limit the choice of the available separation conditions. Also, as the signal varies with the changing concentration of the organic modifier, a post-column compensation and addition of an internal standard is necessary.

The most frequently used chromatographic separation mechanisms include:

a) Hydrophilic ion interaction liquid chromatography (HILIC). The technique was introduced to metal speciation analysis (coupled with ICP MS detection) by Ouerdane et al. [67]. It enables the separation of polar and hydrophilic metal compounds on a polar stationary phase.

b) Reversed phase chromatography. It was used in many original works. The separations are achieved using a polar mobile phase and a non-polar stationary phase and can be useful for the separation of less polar compounds.

c) Size-exclusion LC. The technique allows the fractionation of metal species according to the molecular size, allowing for instance the separation of metal complexes with macromolecules (e.g. humic acids). The separation depends actually more on the hydrodynamical volume than on size. Many non-specific effects make that even species very similar in size can be separated. The advantage is the isocratic elution and ease of quantification. Note that some free ions can be retained on the column.

d) Ion-exchange chromatography. The usually high salt content and the need for change in $\mathrm{pH}$ (and thus the modification of the original speciation) are severe limitations.

The other separation techniques, such as e.g., capillary electrophoresis with ICP MS detection offer attractive features for the study of model systems but are not sufficiently sensitive to tackle real-world environmental problems. 


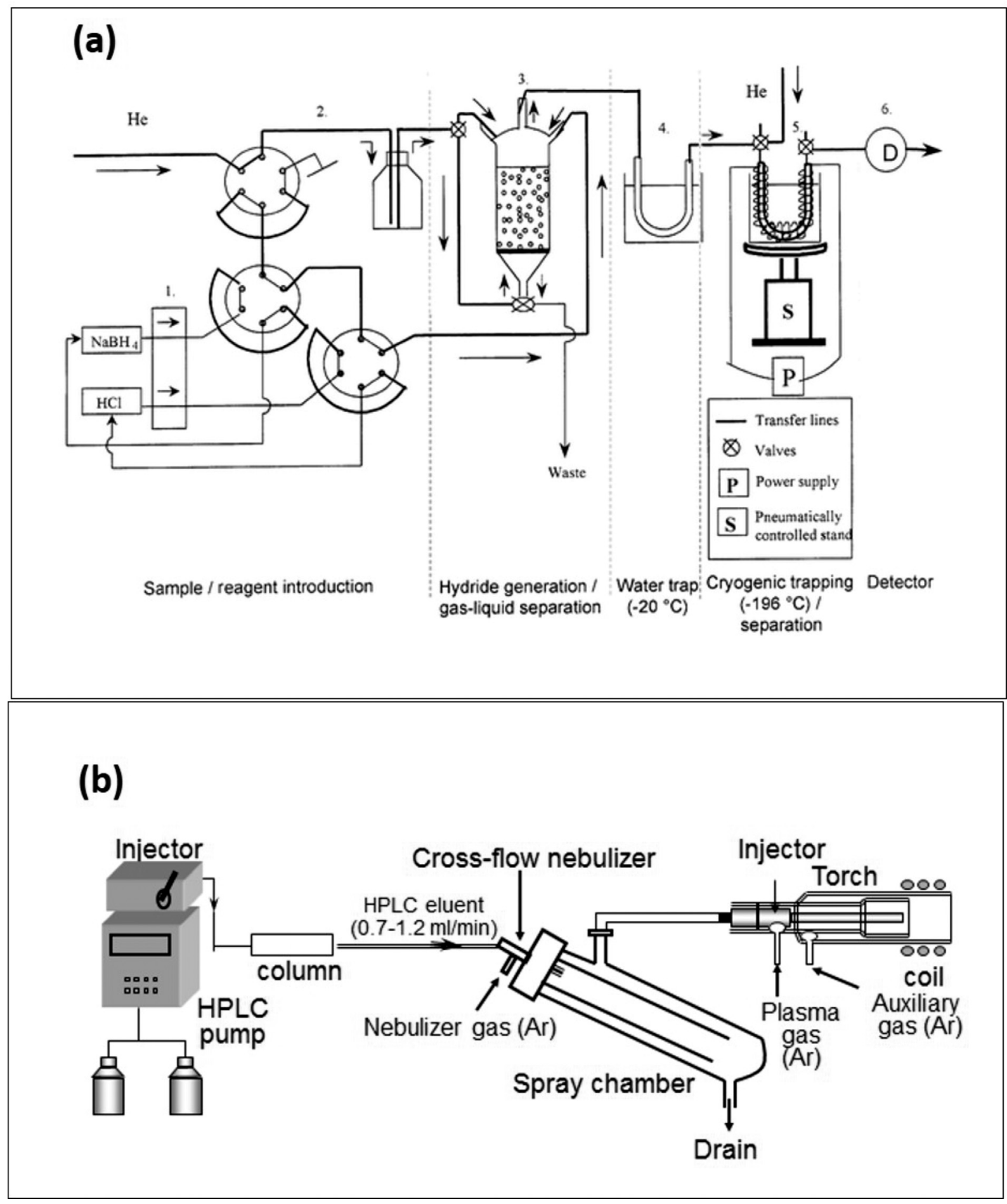

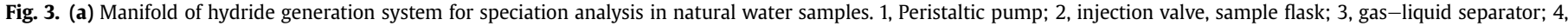
water trap; 5, cryogenic trap; 6, atomic detector (e.g. ICP-MS or -AES, -AFS, -AAS). [60]; (b) HPLC-ICP MS coupling [12].

\subsection{HPLC with parallel ICP MS and electrospray}

ICP MS does not allow the identification of the eluted species in another way than the retention time matching for which standard compounds are required. They are not available for the metabolism products and hence the use of electrospray MS is mandatory. However, as the sensitivity of electrospray MS is strongly influenced by the molecular environment of the metal, the ionization efficiency of the complex and the buffer used, the risk of false negatives is significant. Therefore parallel detection by ICP MS and electrospray MS is essential [64].

\subsection{Sample preparation techniques for speciation analysis}

Ideally, the sample preparation for speciation analysis should be avoided in order to preserve the original species and avoid their 
degradation and/or transformation. In environmental studies this ideal can be achieved for water samples where, however, care has to be taken to prevent potentially harmful bacterial activity during storage. For solid samples, mild extraction conditions are advised; usually neutral $\mathrm{pH}$ buffers are preferred $[25,36,37,68]$.

\section{Applications of coupled techniques to speciation of the individual TCEs}

Applications of coupled techniques to the analysis of TCEs have been summarized in Table 1.

\subsection{Gadolinium}

The challenges related to the speciation of gadolinium include:

a) The quantitative species-specific determination of the individual compounds potentially allowing the compound-specific tracking of the fate of the contrast agent used; concentration detection limits down to the $\mathrm{pg} / \mathrm{L}$ levels are required;

b) Control of the mass balance of the Gd species in a sample, detection of the degradation and transformation of the original compounds. Although the species involved were not formally identified, the amount of Gd found in the effluent exceeds that of the sum of the complexes found, indicating degradation pathways [69], or the occurrence of unknown Gd species such as, e.g. dimers or complexes with matrix constituents, such as, e.g., humic substances.

c) The fate in the environment, complexation with humic and fulvic acid, this challenge is common to all of the rare earth elements

A suitable analytical technique should be able to separate the Gd species from each other, detecting the potentially formed degradation products and accounting for the mass balance. These features are offered by ICP MS. On the level of the separation, the contrast agents can be separated by different chromatographic mechanisms or electrophoresis, such as size exclusion chromatography [70,71], reversed phase chromatography [72], ion exchange chromatography [73] or capillary electrophoresis [74,75], but from the point of view of the resolution and sensitive coupling with ICP MS, hydrophilic interaction liquid chromatography (HILIC) is by far preferred.

HILIC was first used for Gd species by Künnemeyer et al. [76] and has become the principal separation technique for the Gd contrast agents. HILIC was applied for the analysis of biological and environmental samples using different stationary phases, as for example zwitterionic and unboned silica-based phases [76-80]. Zwitterionic stationary phase with different charge in the head functional group and positioning (phosphorylcholine instead of sulfobetaine group) was also used. Diol-based stationary phase in combination with sample introduction by ultrasonic nebulization allowed achievement of superior limits of detection [77]. Mostly cyclic contrast like Gd-BT-DO3A, Gd-DOTA, Gd-DTPA were determined during analysis of environmental samples (Fig. 4), which could be explained by the fact that cyclic complexes are more stable compared to linear compounds.

On the level of detection, the best performance in terms of detection limits was observed by using an ultrasonic nebuliser with subsequent desolvation as the interface [77] and a sector-field instrument operated in the low-resolution (300) mode. The detection limits achieved were down to a few ng/L [78].

HILIC-ICP MS coupling is able to detect unknown compounds [69]. The presence of peaks that are not known Gd complexes used as contrast agents, indicates that species transformation or association with matrix constituents took place during sludge treatment. Further research is necessary to investigate the nature of the Gd compounds in order to evaluate the impact of their release into the environment.

\subsubsection{Analytical performance and quality assurance/quality control} $(\mathrm{QA} / \mathrm{QC})$ procedures for gadolinium speciation analysis

The limits of detection (LOD), limits of quantification (LOQ) values, calibration curve correlation coefficient (above 0.99 in all studies) and relative standard deviation of measurements $(0.2-13 \%)$ were given in the majority of cited studies $[20,21,76,77,79-82]$. The LOD was mainly determined by means of a signal to noise ratio of three $(\mathrm{S} / \mathrm{N}=3)$, while the LOQ was determined by means of a signal to noise ratio of $10(\mathrm{~S} / \mathrm{N}=10)$. In some cases, enrichment techniques had to be applied to achieve satisfactory LODs and LOQs $[21,80]$. Furthermore, the recovery from the column was also reported [77,78,81]. Due to the fact, that standard reference materials for assessment of the applicability of developed methods are not available, the procedures have been validated using standard additions on the matrix [81], comparison of results obtained by direct ICP-MS with those obtained by LA/ HPLC-ICP-MS $[21,79,80]$. A possible instrumental drift was checked by periodical injections of a control standard solution [76].

\subsection{Thallium}

Thallium occurs in a large variety of species in the environment of various, usually low, thermodynamic stability (e.g. $\mathrm{TlHCO}_{3}$, $\mathrm{TlSO}_{4}^{-}, \mathrm{TlCl}, \mathrm{Tl}-$ fulvate [38]), which escape the analytical capabilities of the methods available. Therefore, the speciation analysis refers to the discrimination between the $\mathrm{Tl}(\mathrm{I})$ and $\mathrm{Tl}(\mathrm{III})$ oxidation states with the question of $\mathrm{Me}_{2} \mathrm{Tl}^{+}$being specifically addressed. Thallium in fresh waters occurs at low ng/L level [38] and the analysis of seawater is further complicated because of the presence of salt [83].

A variety of methods based on the selective extraction of either $\mathrm{Tl}(\mathrm{I})$ or $\mathrm{Tl}(\mathrm{III})$ by liquid-liquid or solid-phase extraction (SPE) were developed for the discrimination between the two oxidation states of thallium. The extraction step is followed by the determination of the total $\mathrm{Tl}$ in both fractions usually by spectrophotometry, electrochemistry or graphite furnace AAS. These methods were comprehensively reviewed [38]. They are validated by mass balance of $\mathrm{Tl}$ but do not provide a formal confirmation of the identity of the species detected.

\subsubsection{Stability of the $\mathrm{Tl}$ oxidation states}

The stability of $\mathrm{Tl}(\mathrm{I})$ and $\mathrm{Tl}(\mathrm{III})$ depends on the type of sample and environmental conditions [84]. Sample acidification only was inadequate to maintain the original distribution $\mathrm{Tl}(\mathrm{I})$ and $\mathrm{Tl}(\mathrm{III})$; DTPA addition was found to have a stabilizing effect [85]. A sample preparation step raises potentially a risk of changes in speciation but a comparison between HPLC-ICP MS and direct speciation of Tl in a plant by XANES $[37,86]$ showed coherent results.

\subsubsection{Chromatographic methods with $\mathrm{Tl}$ specific detection}

HPLC has the advantage that the required sample volume is small $(10-1000 \mu \mathrm{L})$ and the secondary redox redistribution artefacts are minimized as well as the loss of analytes [85]. Also, the identity of the species can be confirmed by the retention time matching with a standard. The larger availability in analytical laboratories of ICP MS with the detection limits in the $\mathrm{ng} / \mathrm{L}$ (0.7-300 ng/L] range $[37,38,87,88]$ and the possibility of isotope dilution (Tl has two stable isotopes: ${ }^{203} \mathrm{Tl}$ and ${ }^{205} \mathrm{Tl}$ ) opened a variety of possibilities for $\mathrm{Tl}$ speciation.

The chromatography is mostly based on the conversion of all of the $\mathrm{Tl}(\mathrm{III})$ forms present into a DTPA (pentacarboxymethyldiethylenetriamine) complex. The advantages include (i) 
Table 1

Applications of coupled techniques in speciation analysis of the TCEs.

\begin{tabular}{|c|c|c|c|c|c|c|c|}
\hline Sample & Element concentration & Sample preparation & $\begin{array}{l}\text { Separation } \\
\text { method }\end{array}$ & Detection & Species found & $\begin{array}{l}\text { Detection limit } \\
\left(\mathrm{ng} \mathrm{L}^{-1}\right)\end{array}$ & Ref \\
\hline \multicolumn{8}{|l|}{ Gadolinium } \\
\hline Waste water & $2-58$ g per day & $\begin{array}{l}\text { Filtration and acidification } \\
\text { with } \mathrm{HNO}_{3}\end{array}$ & HILIC & ID ICP-SFMS & $\begin{array}{l}\text { Gd-DOTA } \\
\text { Gd-DTPA } \\
\text { Gd-BT-DO3A }\end{array}$ & 130 & [69] \\
\hline Surface water & $82-307 \mathrm{pmol} \mathrm{L}^{-1}$ & Filtration and acidification & HILIC & ICP-MS & Gd-DOTA & $\leq 20 \mathrm{pmol} \mathrm{L}^{-1}$ & {$[77]$} \\
\hline Ground filtrate & $107-274 \mathrm{pmol} \mathrm{L}^{-1}$ & with $\mathrm{HNO}_{3}$ & & & Gd-DTPA & & \\
\hline Drinking water & $100-298 \mathrm{pmol} \mathrm{L}^{-1}$ & & & & Gd-BT-DO3A & & \\
\hline $\begin{array}{l}\text { Plant - model experiment } \\
\text { River water }\end{array}$ & $50-990 \mathrm{ng} \mathrm{L}^{-1}$ & $\begin{array}{l}\text { Extraction with water } \\
\text { Filtration and acidification } \\
\text { with } \mathrm{HNO}_{3}\end{array}$ & HILIC & ICP-MS & $\begin{array}{l}\text { Gd-DOTA } \\
\text { Gd-BT-DO3A } \\
\text { Gd-DTPA } \\
\text { Gd-BOPTA } \\
\text { Gd-DTPA-BMA }\end{array}$ & $\begin{array}{l}51 \pm 11 \\
2 \pm 1 \text { (after } \\
\text { surface } \\
\text { evaporation) }\end{array}$ & {$[21]$} \\
\hline Tap water & $2-57 \mathrm{ng} \mathrm{L}^{-1}$ & Filtration & ZIC-cHILIC & ICP-MS & $\begin{array}{l}\text { Gd-DOTA } \\
\text { Gd-BT-DO3A } \\
\text { Gd-BOPTA }\end{array}$ & $1.4-3.5$ & [81] \\
\hline Surface water & $\begin{array}{l}0.55-7.36 \mathrm{nmol} \mathrm{L}^{-1} \\
\text { (total) }\end{array}$ & $\begin{array}{l}\text { Filtration and acidification } \\
\text { with } \mathrm{HNO}_{3}\end{array}$ & HILIC & ID ICP-SFMS & $\begin{array}{l}\text { Gd-DOTA } \\
\text { Gd-DTPA } \\
\text { Gd-BT-DO3A }\end{array}$ & $\begin{array}{l}0.10 \mathrm{nmol} \mathrm{L}^{-1} \\
0.09 \mathrm{nmol} \mathrm{L}^{-1} \\
0.08 \mathrm{nmol} \mathrm{L}^{-1}\end{array}$ & {$[78]$} \\
\hline Water (model experiment) & n.d. & $\begin{array}{l}\text { Filtration and acidification } \\
\text { with } \mathrm{HNO}_{3}\end{array}$ & HILIC & $\begin{array}{l}\text { ICP-MS } \\
\text { ESI-MS }\end{array}$ & $\begin{array}{l}\text { Gd-DOTA } \\
\text { Gd-DTPA } \\
\text { Gd-BT-DO3A }\end{array}$ & n.d. & [20] \\
\hline $\begin{array}{l}\text { Wastewater } \\
\text { Hospital effluent } \\
\text { Sewage effluent }\end{array}$ & $\begin{array}{l}1.8-13.6 \mathrm{nmol} \mathrm{L}^{-1} \\
\leq \mathrm{LOD}-27.9 \mathrm{nmol} \mathrm{L}^{-1} \\
23.9-26.5 \mathrm{nmol} \mathrm{L}^{-1}\end{array}$ & Filtration & HILIC & ICP-MS & $\begin{array}{l}\text { Gd-DOTA } \\
\text { Gd-BT-DO3A } \\
\text { Gd-BOPTA }\end{array}$ & $0.2-1 \mathrm{nmol} \mathrm{L}^{-1}$ & [76] \\
\hline $\begin{array}{l}\text { River water } \\
\text { Wastewater }\end{array}$ & $\begin{array}{l}12-436 \mathrm{ng} \mathrm{L}^{-1} \\
97-122 \mathrm{ng} \mathrm{L}^{-1}\end{array}$ & Filtration $(0.45 \mu \mathrm{m})$ & ZIC-HILIC & ICP-MS & $\begin{array}{l}\text { Gd-DOTA } \\
\text { Gd-DTPA } \\
\text { Gd-BT-DO3A }\end{array}$ & $22 \pm 5$ & {$[80]$} \\
\hline $\begin{array}{l}\text { REE (other than Gd) } \\
\text { Model experiment }\end{array}$ & Gd, Eu, Sm - n.d. & $\begin{array}{l}\text { Mixing of Ln3+ with humic } \\
\text { acids }\end{array}$ & $\mathrm{CE}$ & ICP-MS & $\begin{array}{l}\mathrm{Gd}^{3+}, \mathrm{Eu}^{3+} \\
\mathrm{Gd}-, \mathrm{Eu}-\mathrm{HA}\end{array}$ & $\begin{array}{l}\text { n.d. } \\
\mathrm{Eu}-150\end{array}$ & $\begin{array}{l}{[26]} \\
{[28]}\end{array}$ \\
\hline $\begin{array}{l}\text { Model experiment (HA } \\
\text { extracted from soil or } \\
\text { river) }\end{array}$ & Gd, Eu - n.d. & $\begin{array}{l}\text { Mixing of Ln with natural } \\
\text { organic matter (NOM) }\end{array}$ & $\mathrm{CE}$ & ICP-MS & $\begin{array}{l}\mathrm{Gd}^{3+}, \mathrm{Eu}^{3+} \\
\mathrm{Sm}-, \mathrm{Gd}-, \mathrm{Eu}-\mathrm{HA}\end{array}$ & n.d. & {$[25]$} \\
\hline Lake water & $\begin{array}{l}\mathrm{Y}-3.8-13 \mathrm{ng} \mathrm{L}^{-1} \\
\mathrm{La}-2-4 \mathrm{ng} \mathrm{L}^{-1} \\
\mathrm{Ce}-3.1-6.5 \mathrm{ng} \mathrm{L}^{-1} \\
\mathrm{Pr}-0.40-0.91 \mathrm{ng} \mathrm{L}^{-1}\end{array}$ & $\begin{array}{l}\text { Filtration and } \\
\text { preconcentration }\end{array}$ & SEC & UV-ICP-MS & Large metal complexes & n.d. & [22] \\
\hline \multicolumn{8}{|l|}{ Thallium } \\
\hline Plant & $134.9 \pm 7.2 \mu \mathrm{g} \mathrm{g}^{-1}$ & $\begin{array}{l}\text { Extraction with } \\
\mathrm{CH}_{3} \mathrm{COONH}_{4} \text { and DTPA }\end{array}$ & $(\mathrm{AEC})$ & ICP-MS & $\mathrm{Tl}(\mathrm{I}), \mathrm{Tl}(\mathrm{III})-\mathrm{DTPA}$ & n.d. & [36] \\
\hline Plant & $4900 \mu \mathrm{g} \mathrm{g}^{-1}$ & $\begin{array}{l}\text { Extraction with } \\
\mathrm{CH}_{3} \mathrm{COONH}_{4} \text { and DTPA }\end{array}$ & $\begin{array}{l}\text { AEC/SEC } \\
\text { SEC }\end{array}$ & $\begin{array}{l}\text { ICP-MS } \\
\text { ES-MS }\end{array}$ & $\begin{array}{l}\mathrm{Tl}(\mathrm{I}), \mathrm{Tl}(\mathrm{III})-\mathrm{DTPA} \\
\mathrm{Tl}^{+}\end{array}$ & 300 & [37] \\
\hline River water & n.d. & None & $\begin{array}{l}\text { IC } \\
\text { RPLC }\end{array}$ & $\begin{array}{l}\text { ICP-MS } \\
\text { APCI-MS }\end{array}$ & $\begin{array}{l}\mathrm{Tl}^{+} \\
\left(\mathrm{CH}_{3}\right)_{2} \mathrm{Tl}^{+}\end{array}$ & $\begin{array}{l}12.0 \\
300\end{array}$ & [38] \\
\hline $\begin{array}{l}\text { Lake water } \\
\text { Lake water (forest) }\end{array}$ & $0.01-0.26 \mu \mathrm{g} \mathrm{L}^{-1}$ & $\begin{array}{l}\text { Acidification with } \mathrm{HNO}_{3} \\
\text { and DTPA }\end{array}$ & CEC & ICP-MS & $\mathrm{Tl}(\mathrm{I}), \mathrm{Tl}(\mathrm{III})-\mathrm{DTPA}$ & $\begin{array}{l}0.7-3.0(\mathrm{Tl}(\mathrm{III})) \\
9.0-25.0(\mathrm{Tl}(\mathrm{I}))\end{array}$ & [85] \\
\hline Water & $0.003 \pm 0.001 \mu \mathrm{g} \mathrm{L}^{-1}$ & Direct injection (water) & RPLC & ICP-MS & $\mathrm{Tl}(\mathrm{I}), \mathrm{Tl}(\mathrm{III})-\mathrm{DTPA}$ & 2.0 & [87] \\
\hline Plant & $7.5-33.6 \mathrm{ng} \mathrm{g}^{-1}$ & $\begin{array}{l}\text { Treated with } \mathrm{CH}_{3} \mathrm{COONH}_{4} \\
\text { and DTPA (plant) }\end{array}$ & & & & & \\
\hline River water & $0.01-4.97 \mu \mathrm{g} \mathrm{L}^{-1}$ & Filtration $(0.45 \mu \mathrm{m})$ & IC (AEC) & ICP-MS & $\mathrm{Tl}(\mathrm{I}), \mathrm{Tl}(\mathrm{III})-\mathrm{DTPA}$ & 11.0 & [88] \\
\hline Ocean water & $1.6-19.0 \mathrm{ng} \mathrm{L}^{-1}$ & $\begin{array}{l}\text { Extraction of DDTC } \\
\text { complex into MIBK }\end{array}$ & PTI & IDMS & $\left(\mathrm{CH}_{3}\right)_{2} \mathrm{Tl}^{+}$ & 0.4 & [39] \\
\hline $\begin{array}{l}\text { Plant leaves } \\
\text { Dried soil }\end{array}$ & $\begin{array}{l}0.11 \pm 0.01 \mu \mathrm{g} \mathrm{g}^{-1} \\
0.06 \pm 0.01 \mu \mathrm{g} \mathrm{g}^{-1}\end{array}$ & $\begin{array}{l}\text { Extraction with } \\
\mathrm{CH}_{3} \mathrm{COONH}_{4} \text { and DTPA } \\
\text { Extraction with EDTA }\end{array}$ & IC (AEC) & $\begin{array}{l}\text { ICP-MS } \\
\text { DPASV }\end{array}$ & $\mathrm{Tl}(\mathrm{I}), \mathrm{Tl}(\mathrm{III})-\mathrm{DTPA}$ & n.d. & [68] \\
\hline \multicolumn{8}{|l|}{ Platinum group elements (PGE) } \\
\hline Plant - model experiment & $\begin{array}{l}\text { Leaves: } \mathrm{Pt}-1.9 \\
-70.6 \mu \mathrm{g} \mathrm{g}^{-1} \\
\mathrm{Pd}-0.4-8.3 \mu \mathrm{g} \mathrm{g}^{-1} \\
\mathrm{Rh}-0.08-1.16 \mu \mathrm{g} \mathrm{g}^{-1} \\
\text { Roots: } \mathrm{Pt}-1910 \\
-6230 \mu \mathrm{g} \mathrm{g}^{-1} \\
\mathrm{Pd}-4000 \\
-16,270 \mu \mathrm{g} \mathrm{g}^{-1} \\
\mathrm{Rh}-840-4360 \mu \mathrm{g} \mathrm{g}^{-1}\end{array}$ & Extraction with water & SEC & ICP-SFMS & $\begin{array}{l}\text { Unknown compounds: } \\
\text { in roots: Pt-5, } \\
\text { Pd-7, Rh-2; } \\
\text { in leaves: Pt-8, Pd-4, } \\
\text { Rh-2 }\end{array}$ & $\begin{array}{l}1.3(\mathrm{Pt}) \\
1.9(\mathrm{Pd}) \\
0.8(\mathrm{Rh})\end{array}$ & [49] \\
\hline $\begin{array}{l}\text { Road dust spiked with Pt(II) } \\
\text { and Pt(IV) }\end{array}$ & $\mathrm{Pt}-541 \pm 10 \mu \mathrm{g} \mathrm{kg}^{-1}$ & $\begin{array}{l}\text { Treated with } \mathrm{NaCl} \text { and } \mathrm{HCl} \text {, } \\
\text { Tris, EDTA/MeOH/NaOH }\end{array}$ & IC & ICP-MS & & n.d. & [93] \\
\hline $\begin{array}{l}\text { Wastewater } \\
\text { spiked with cisplatin }\end{array}$ & $\begin{array}{l}\mathrm{Pt}-14.4-352 \mu \mathrm{g} \mathrm{L}^{-1} \\
\mathrm{Pt}-5.9-23.3 \mu \mathrm{g} \mathrm{L}^{-1}\end{array}$ & $\begin{array}{l}\text { Filtration and acidification } \\
\text { of samples }\left(\mathrm{HNO}_{3}\right)\end{array}$ & ZIC-HILIC & $\begin{array}{l}\text { ICP-MS } \\
\text { ID-ICP-MS }\end{array}$ & & 5.0 & [45] \\
\hline $\begin{array}{l}\text { Model fresh water spiked } \\
\text { by } \mathrm{Rh}^{3+} \text { solution }\end{array}$ & n.d. & none & SEC & ICP-MS & $\begin{array}{l}\mathrm{Rh}-\text { mainly } \\
\text { hydroxylated species }\end{array}$ & n.d. & [94] \\
\hline
\end{tabular}


Table 1 (continued)

\begin{tabular}{|c|c|c|c|c|c|c|c|}
\hline Sample & Element concentration & Sample preparation & $\begin{array}{l}\text { Separation } \\
\text { method }\end{array}$ & Detection & Species found & $\begin{array}{l}\text { Detection limit } \\
\left(n \mathrm{n} \mathrm{L}^{-1}\right)\end{array}$ & Ref \\
\hline \multicolumn{8}{|l|}{ Tellurium } \\
\hline Compost samples & n.d. & $\begin{array}{l}\text { Treated with citric acid/ } \\
\text { citrate buffer, } \mathrm{NaBH}_{4} \text { and } \\
\mathrm{HCl} \text {, purge with } \mathrm{He}\end{array}$ & HG-GC & ICP-MS & DMTe & $1-40 \mathrm{pg}$ & [51] \\
\hline Waste water & $6-2881 \mu \mathrm{g} \mathrm{L}^{-1}$ & $\begin{array}{l}\text { Samples centrifugation, } \\
\text { filtration } \\
\text { Treated with } \mathrm{HCl}(\mathrm{Tl}(\mathrm{VI}) \\
->\mathrm{Tl}(\mathrm{IV}))\end{array}$ & $\mathrm{IC}(\mathrm{AEC})$ & HG-AFS & $\mathrm{Te}(\mathrm{IV}), \mathrm{Te}(\mathrm{VI})$ & $\begin{array}{l}690-\mathrm{Tl}(\mathrm{VI}) \\
760-\mathrm{Tl}(\mathrm{IV})\end{array}$ & [50] \\
\hline $\begin{array}{l}\text { Garlic leaves } \\
\text { (Allium sativum) - model } \\
\quad \text { experiment }\end{array}$ & $116.0 \mu \mathrm{g} \mathrm{g}^{-1}$ & $\begin{array}{l}\text { Treated with water } \\
\text { Treated with } \mathrm{HNO}_{3} \text { (total } \\
\text { content analysis) }\end{array}$ & SEC & $\begin{array}{l}\text { ICP-MS } \\
\text { ESI-MS/MS }\end{array}$ & $\begin{array}{l}\text { Te }(\mathrm{VI}) \\
\text { MeTeCysO } \\
\text { MeTeSCys }\end{array}$ & n.d. & [52] \\
\hline \multicolumn{8}{|l|}{ Germanium } \\
\hline Soil additive & $320 \mathrm{mg} \mathrm{L}^{-1}$ & $\begin{array}{l}\text { Derivatization by the ethyl } \\
\text { chloroformate }\end{array}$ & GC & MIP-AED & $\begin{array}{l}\text { Ge-132 (germanium } \\
\text { sesquioxide) }\end{array}$ & 0.173 & [54] \\
\hline Surface water samples & $\begin{array}{l}\mathrm{Ge}^{4+}-0.36-8.90 \\
\mathrm{MeGe}-0.54-21.0 \\
\mathrm{Me}_{2} \mathrm{Ge}-0.42-5.10 \\
\mathrm{Me}_{3} \mathrm{Ge}-\text { n.d. }\end{array}$ & $\begin{array}{l}\text { Filtration under } \mathrm{He} \\
\text { atmosphere }\end{array}$ & $\begin{array}{l}\text { LV-HG-CT-GC } \\
\text { CF-HG-CT-GC }\end{array}$ & ICP-MS & $\begin{array}{l}\mathrm{Ge}^{4+} \\
\mathrm{MeGe} \\
\mathrm{Me}_{2} \mathrm{Ge} \\
\mathrm{Me}_{3} \mathrm{Ge}\end{array}$ & $0.001-0.080$ & [60] \\
\hline
\end{tabular}

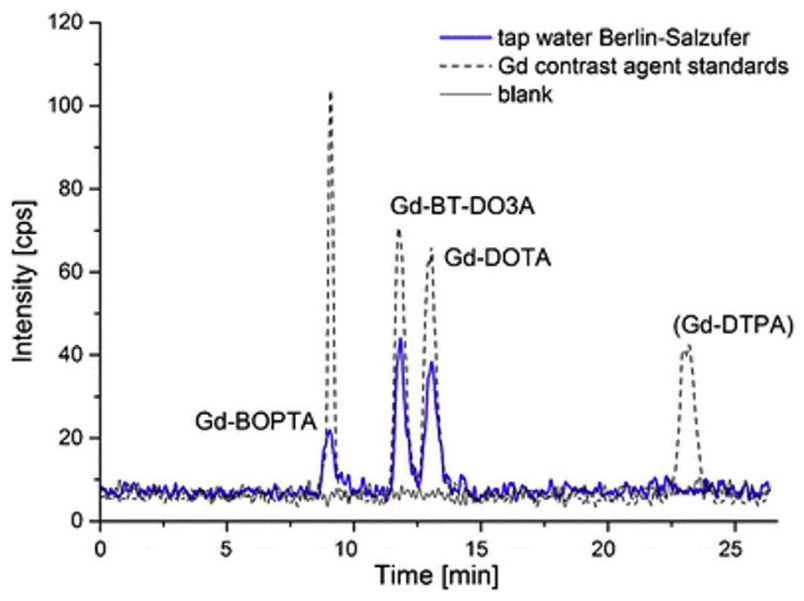

Fig. 4. HILIC-ICP-MS chromatogram of gadolinium-based contrast reagents in tap water of Berlin [81].

the high stability of the Tl(III)-DTPA complex (pK 46 [89]) increasing the probability of the transformation of all the $\mathrm{Tl}(\mathrm{III})$ species into a single $\mathrm{Tl}(\mathrm{III})-\mathrm{DTPA}$ complex, and (ii) its strongly anionic character, allowing distinction from the cationic $\mathrm{Tl}^{+}$species. The chromatographic mechanisms reported included:

a) cation-exchange HPLC $[85,90]$ in which the Tl(III)-DTPA complex is found in the void of cation-exchange while $\mathrm{Tl}^{+}$ is retained and elutes as the second peak. Note that baseline separation by cation exchange is difficult for the nonderivatized forms [90].

b) anion-exchange HPLC $[36,83,88]$ in which the Tl(III)-DTPA complex is retained whereas $\mathrm{Tl}^{+}$elutes in the void.

c) reversed-phase HPLC in which $\mathrm{Tl}(\mathrm{III})(\mathrm{DATA})$ is ion paired with tetrabutylammonium phosphate and separated from $\mathrm{Tl}^{+}$[87].

d) size-exclusion LC using the different hydrodynamic volumes of $\mathrm{Tl}^{+}$and $\mathrm{Tl}(\mathrm{III})$-DTPA species [37].

The different separation mechanisms were compared by Nolan et al. [37]. Representative chromatograms are shown in Fig. 5.

Dimethylthallium was determined by enrichment on an anionexchanger column and selective extraction of the species followed by analysis by positive thermal ionization isotope dilution mass spectrometry with a detection limit of $0.4 \mathrm{ng} / \mathrm{L}$ for $0.5 \mathrm{~L}$ water [39].
4.2.3. Analytical performance and quality assurance/quality control $(\mathrm{QA} / \mathrm{QC})$ procedures for thallium speciation analysis.

The LOD and LOQ values, linearity and RSD were given for most of the studies presented in this review [37-39,68,85,87,88]. The recovery from the chromatographic column was determined by Nolan et al. [37]. Only in one case validation of the proposed method was performed with the use of standard reference material of water [87]. In the most cases, the procedures have been validated by addition of standard solution on the matrix [37-39,68,85,88]. The quality of obtained results of thallium concentration was also evaluated by the intermethod comparison of AEC-ICP-MS with voltammetry as a reference method $[36,68]$. Comparison of results generated by LC-MS and IC-ICP-MS was presented [38]. A control standard solution was periodically measured to compensate for the effect of possible instrumental drift [68].

\subsection{Platinum group elements}

The challenges to speciation of PGE in environmental samples require highly sophisticated methods due to the very low concentrations and the fast species transformations [91]. The statement made 15 years ago is still valid and the relevant literature is very scarce.

\subsubsection{Speciation of PGEs in road dust}

There is no method capable of the direct solid state speciation of PGEs in dust. Therefore, leaching procedures are necessary to make the PGE species accessible to the chemical characterization. A tradeoff between the preservation of the identity of the species and the extraction efficiency $[92,93]$ is inevitable; the extraction efficiencies with mild (neutral $\mathrm{pH}$, weakly complexing) buffer lead to the recoveries of only ca. $5 \%$ of total Pt $[92,93]$ at concentrations insufficient to produce signals from real-world samples. Some data were published on spiked samples [92,93] with the risk of the different behaviour of the spike and the endogenously present species. The hypothesis $[92,93]$ that the concentrations of mobile Pt species in road dust reaches detectable and ecotoxicologically relevant levels still waits to be validated.

Chromatographic results suggest that inorganic Rh speciation in fresh waters is dominated by negatively charged hydroxides which would imply their low affinity for the negatively charged suspended particulate matter surface [94]. Again, a considerable (at least 2 orders of magnitude) increase in the detection limits of the analytical methodology is required to validate the observation obtained for spiked samples in real environmental conditions. 

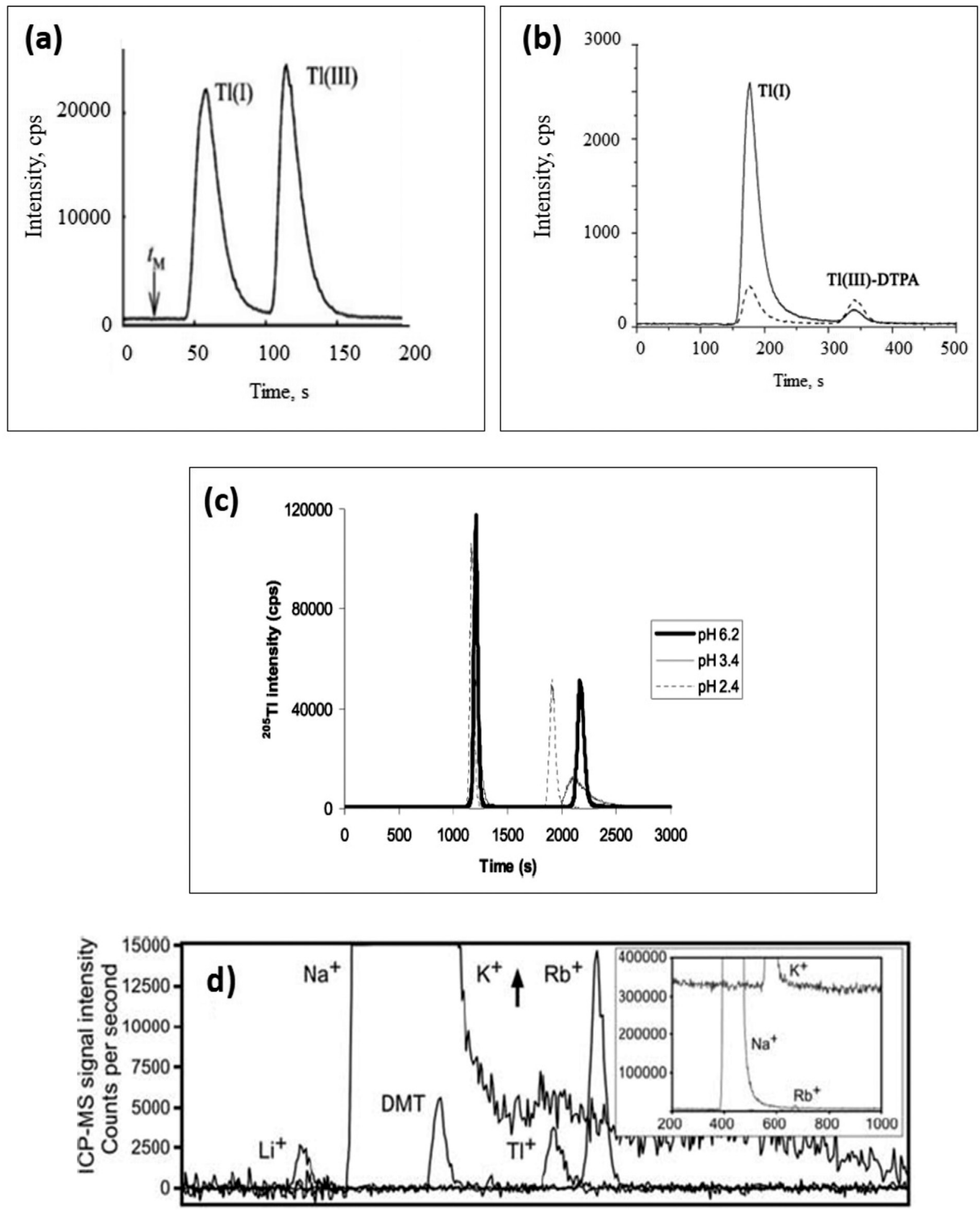

Fig. 5. Separation of thallium species by HPLC-ICP MS: (a) RPLC chromatogram: solution containing $1 \mu \mathrm{g} / \mathrm{L}$ of TI(I) and TI(III), tM: void volume [87], (b) AEC chromatograms: extract of leaves of S. alba diluted 1:10 (solid line), mixed $1 \mu \mathrm{g} / \mathrm{L}$ standards of Tl(III)-DTPA and Tl(I) (dashed line) [83], (c) SEC chromatogram: mixture of $50 \mu \mathrm{g} / \mathrm{L}$ standards of Tl(III)-DTPA and $\mathrm{Tl}(\mathrm{I})$, analysis performed at three different $\mathrm{pH}$ values: (i) 6.2, (ii) 3.4, (iii) 2.4 [37], (d) CEC chromatograms: tap water with addition of $\mathrm{Tl}^{+}$(200 ng/L) and DMT (360 ng/L) Inset shows signals of $\mathrm{K}+, \mathrm{Na}+, \mathrm{Rb}+[37]$.

\subsubsection{Metabolism of PGEs by plants and probing their speciation}

Bioaccumulation by plants was studied in hydroponic and at environmentally relevant concentrations [49]. The metals were strongly retained in roots. Nevertheless part of them (ca. 10\%) was not only transported to leaves but also metabolized. Water soluble fraction contains ca. $70 \%$ of Pt and Pd and ca. 40\% for Rh. The lower molecular mass fraction ( $<10 \mathrm{kDa}$ ) studied by SEC (exclusion limit $3000 \mathrm{Da}$ ) with ICP MS detection (a representative chromatogram is shown in Fig. 6) indicated the distribution of Pt over the whole mass range of the chromatograms producing 6 peaks. Palladium 
was also efficiently metabolized ( 4 peaks) whereas Rh produced a major peak at the exclusion volume of the column. The species could not be identified but the co-elution with $\mathrm{Ca}, \mathrm{Cu}, \mathrm{S}$ and $\mathrm{C}$ allowed the hypothesis that the ligands might be phytochelatins or carbohydrates. Despite the interest of the study from the fundamental research perspective, only small amounts of metals taken up are really metabolized and transported to leaves and the probability to enter food chain is very low.

\subsubsection{Speciation of Pt released in hospital effluents}

Although three Pt drugs (cisplatin, oxaliplatin and carboplatin) are authorized for clinical use, cisplatin is the most widely used and all the studies concerning Pt speciation in the environment (hospital effluents and waste waters) have concerned this drug only. Cisplatin and its degradation products vary in terms of hydrophobicity $[45,95]$ and can be separated by reversed-phase HPLC [95] or HILIC [45]. The latter shows baseline resolution of cisplatin and its hydrolysis products: monohydroxycisplatin, diaquacisplatin and monohydroxycisplatin. The detection limits were $0.2 \mathrm{ng} / \mathrm{mL}$ Pt for cis-Pt and were an order of magnitude higher than for its hydrolysis products [45]. The potential for improvement of the detection limits by at least one order of magnitude by coupling HILIC with the latest generation of SF ICP MS instruments is there and the publication of chromatograms for speciation in effluent and waste water seems to be a question of time.

The impact of PGEs on the environment is rather negligible as they tend to hydrolyse and be adsorbed by suspended particulate matter and humic acids (75\%) thus becoming non-bioavailable.

\subsubsection{Analytical performance and quality assurance/quality control} $(Q A / Q C)$ procedures for speciation analysis of $P G E$

The LOD and linearity were given for platinum speciation procedures $[45,49]$. In the work of Vidmar et al. [45], the full analytical characteristics (including also recovery from the column, RSD and LOQ values) was presented. The proposed procedures have been validated by the standard addition of Pt-species to the sample matrix $[45,92,93]$.

\subsection{Tellurium}

The analytical methodology is custom designed according to three major problems:

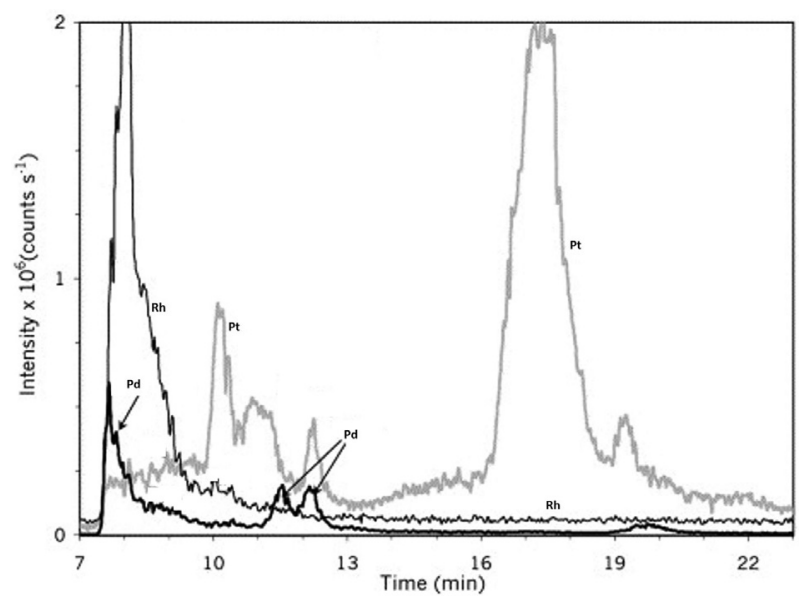

Fig. 6. LC-ICP MS chromatograms (column TSKgel G2500 PWXL, $300 \times 7.8 \mathrm{~mm}$ ) of ${ }^{195} \mathrm{Pt}$ (multiplied by 4$),{ }^{103} \mathrm{Rh}$, and ${ }^{108} \mathrm{Pd}$ of leaf extract (plant after 5 days of treatment with PGEs). (adapted from Ref. [49]).

\subsubsection{Speciation of tellurate $\left(\mathrm{TeO}_{4}^{2-}\right)$ and tellurite $\left(\mathrm{TeO}_{3}^{2-}\right)$}

HPLC can readily be optimized for the separation of $\mathrm{Te}(\mathrm{IV})$ and $\mathrm{Te}(\mathrm{VI})$ [50-52]. The conversion of $\mathrm{Te}$ into strongly anioniccomplexes with EDTA and hydrogen phthalate was reported to improve the separation [50]. In terms of detection, ICP MS offers sub-ng/mL detection limits in HPLC $(0.7 \mathrm{ng} / \mathrm{mL}$ [50]) that are matched by those of post-column hydride generation AAS or AFS.

\subsubsection{Speciation of volatile tellurium compounds}

The volatile Te compounds are measured after derivatization with $\mathrm{NaBH}_{4}$ by purge from relatively large volume of aqueous solution/slurry, preconcentrated by cryofocussing and separated by GC with ICP MS detection. The absolute detection limits down to 6 pg could be reached [96]. Seven Te species, namely methylated, ethylated and mixed methyl-ethylated compounds, were detected [97].

\subsubsection{Speciation of tellurium in plants}

A method for the identification of the species synthetized in garlic by HPLC with the parallel ICP MS and electrospray MS detection was developed [52]. Two metabolites: Te-methyltellurocysteine oxide and S-methyltellurosulfide were formally identified [52]. The recovery of the extraction of Te species from garlic into water was about $50 \%$.

\subsubsection{Analytical performance and quality assurance/quality control} $(\mathrm{Q} A / \mathrm{QC})$ procedures for speciation analysis of tellurium

The LOD, linearity in different concentration range and RSD were given for two of four presented studies [50,51]. As no certified reference materials are available for Te speciation analysis, the proposed methods were evaluated by analysis of tellurium species in spiked water or compost samples. Species identification was additionally validated by GC-MS [51]. Additionally, a control standard solution was periodically measured to compensate for instrumental drift [51].

\subsection{Other elements}

\subsubsection{Rare earth elements (other than Gd-MRI agents)}

Ultrafiltration was employed as a means for the preconcentration of large organic molecules $(>10,000)$ prior to size-exclusion LC-ICP MS analysis of surface waters [22]. Lanthanides were found at the low-ppt and sub-ppt levels. Light lanthanides were relatively more adsorbed on particulate matter whether heavier ones formed preferentially water-soluble complexes. More than $50 \%$ of the total mass of lanthanides were present as complexes with molecular masses higher than 10,000 [22]. Binding patterns of lanthanides with humic acids in model laboratory experiments were established CZE-ICP MS [25-28].

\subsubsection{Germanium}

Germanium sesquioxide was determined in soil additives by GC-MIP AES after derivatization [54] but methods developed for drugs by anion-exchange HPLC-ICP MS [98] can be probably readily transferred to environmental applications. Methyl germanium compounds can be readily determined in environmental water by hydride generation purge and trap ICP MS with detection limits down to $1 \mathrm{pg} / \mathrm{L}$ [60]. The LOD and LOQ values obtained with MIP AES detection was 3 orders of magnitude worse [54]. The latter procedure has been validated using standard additions on the matrix [54]. Comparison of method detection limit vs. absolute detection limit of germanium was presented in one of study [60]. 


\section{Conclusions}

Coupled techniques which have revolutionized our access to information on speciation of many elements in the environment and biological matrices in the 90ties, are becoming increasingly popular for speciation of technologically critical elements, mostly because of their extremely low detection limits that are unmatched by other techniques. The wider availability of HPLC with ICP MS detection in environmental laboratories is likely to contribute to more careful optimization studies addressing scientific questions in their very environmental context and the use of speciation information to the interpretation of the environmental cycling of TCEs. Also, potential gains in terms of detection limits (1-2 orders of magnitude) can be achieved in many cases by using optimized LCICP MS interfaces (ultrasonic nebulization with desolvation) and sector field instruments. The observed trend of the miniaturization of the sample preparation and chromatographic separation modules is expected to contribute to more environmentally friendly procedures and the implementation of green chemistry principles.

\section{Acknowledgements}

\section{J. Szpunar appreciated the COST (action 1407) travel grant.}

\section{References}

[1] E.K. Atibu, N. Devarajan, A. Laffite, G. Giuliani, J.A. Salumu, R.C. Muteb C.K. Mulaji, J.-P. Otamonga, V. Elongo, P.T. Mpiana, J. Chemie der Erde Geochem. 76 (2016) 353.

[2] A. Grawunder, D. Merten, I.G. Büche, Environ. Sci. Pollut. Res. 21 (2014) 6812.

[3] B. Peng, A. Piestrzynski, J. Pieczonka, M. Xiao, Y. Wang, S. Xie, X. Tang, C. Yu, Z. Song China, Environ, Geol. 53 (2007) 1277.

[4] G. Protano, F. Riccobono, Environ. Pollut. 117 (2002).

[5] P. Babula, V. Adam, R. Opatrilova, J. Zehnalek, L. Havel, R. Kizek, Environ. Chem. Lett. 6 (2008) 189.

[6] K. Ravindra, L. Bencs, v.G. R, Sci. Total Environ. 318 (2004) 1.

[7] J.J. Rodríguez-Mercado, M.A. Altamirano-Lozano, Drug Chem. Toxicol. 36 (2013) 369.

[8] C.L.S. Wiseman, F. Zereini, Sci. Total Environ. 407 (2009) 2493.

[9] D.M. Templeton, F. Ariese, R. Cornelis, L.G. Danielsson, H. Muntau, H.P. Van Leeuwen, R. Łobiński, Pure Appl. Chem. 72 (2000) 1453.

[10] R. Lobinski, J.S. Becker, H. Haraguchi, B. Sarkar, Pure Appl. Chem. 82 (2010) 493.

[11] R. Łobiński, D. Schaumlöffel, J. Szpunar, Mass Spectrom. Rev. 25 (2006) 255.

[12] R. Lobinski, J. Szpunar, Hyphenated Techniques in Speciation Analysis, RSC Cambridge, 2003.

[13] E.G. Duncan, W.A. Maher, S.D. Foster, Environ. Chem. 12 (2015) 149.

[14] Y. Wang, S. Wang, P. Xu, C. Liu, M. Liu, Y. Wang, C. Wang, C. Zhang, Y. Ge, Rev. Environ. Sci. Biotechnol. 14 (2015) 427.

[15] S. Mounicou, J. Szpunar, R. Lobinski, Chem. Soc. Rev. 38 (2009) 1119.

[16] M. Bau, P. Dulski, Earth Planet. Sci. Lett. 143 (1996) 245.

[17] M. Port, J.M. Idée, C. Medina, C. Robic, M. Sabatou, C. Corot, BioMetals 21 (2008) 469.

[18] S. Kulaksiz, M. Bau, Earth Planet. Sci. Lett. 260 (2007) 361.

[19] Y. Zhu, M. Hoshino, H. Yamada, A. Itoh, H. Haraguchi, Bull. Chem. Soc. Jpn. 77 (2004) 1835

[20] M. Birka, J. Roscher, M. Holtkamp, M. Sperling, U. Karst, Water Res. 91 (2016) 244.

[21] U. Lindner, J. Lingott, S. Richter, N. Jakubowski, U. Panne, Anal. Bioanal. Chem. 405 (2013) 1865.

[22] H. Haraguchi, A. Itoh, C. Kimata, H. Miwa, Analyst 123 (1998) 773.

[23] E. Diatloff, F.W. Smith, C.J. Asher, Ann. Bot. 101 (2008) 971.

[24] J. Saatz, H. Stryhanyuk, D. Vetterlein, N. Musat, M. Otto, T. Reemtsma, H.H. Richnow, B. Daus, Environ. Pollut. 216 (2016) 245.

[25] R. Hahn, C. Hein, J.M. Sander, R. Kautenburger, Appl. Geochem. 78 (2017) 241.

[26] R. Kautenburger, J. Anal. Atomic Spectrom. 24 (2009) 934.

[27] R. Kautenburger, C. Hein, J.M. Sander, H.P. Beck, Anal. Chim. Acta 816 (2014) 50.

[28] J.E. Sonke, V.J.M. Salters, Analyst 129 (2004) 731.

[29] M.A. López Antón, D.A. Spears, M. Díaz Somoano, M.R. Tarazona Martínez, Fuel 105 (2013) 13.

[30] A.L.J. Peter, T. Viraraghavan, Environ. Int. 31 (2005) 493.

[31] G. Repetto, A. del Peso, M. Repetto, in: J.O. Nriagu (Editor), Wiley, NY, 1998.

[32] L.H. Keith, W.A. Telliard, Environ. Sci. Technol. 13 (1979) 416.

[33] B.S. Twining, M.R. Twiss, N.S. Fisher, Environ. Sci. Technol. 37 (2003) 2720.

[34] G.E. Batley, T.M. Florence, J. Electroanal. Chem. 61 (1975) 205.

[35] T.S. Lin, J. Nriagu, Environ. Sci. Technol. 33 (1999) 3394.
[36] B. Krasnodębska-Ostrȩga, M. Asztemborska, J. Golimowski, K. Strusińska, J. Anal. Atomic Spectrom. 23 (2008) 1632.

[37] A. Nolan, D. Schaumlöffel, E. Lombi, L. Oucrdane, R. Łobiński, M. McLaughlin, J. Anal. Atomic Spectrom. 19 (2004) 757.

[38] S. Sindern, J. Schwarzbauer, L. Gronen, A. Görtz, S. Heister, M. Bruchmann, Int. J. Environ. Anal, Chem, 95 (2015) 790.

[39] O.F. Schedlbauer, K.G. Heumann, Anal. Chem. 71 (1999) 5459.

[40] E. Helmers, N. Mergel, R. Barchet, Umweltwissenschaften Schadst. Forsch. 6 (1994) 130.

[41] M.E. Farago, Fresen. J. Anal. Chem. 354 (1996) 660

[42] B. Gómez, M.A. Palacios, M. Gómez, J.L. Sanchez, G. Morrison, S. Rauch, C. McLeod, R. Ma, S. Caroli, A. Alimonti, F. Petrucci, B. Bocca, P. Schramel, M. Zischka, C. Petterson, U. Wass, Sci. Total Environ. 299 (2002) 1.

[43] F. Zereini, F.E. Alt, Anthropogenic Platinum-Group Element Emissions: their impact on man and environment, Springer Verlag, Heidelberg, 2000.

[44] K. Kümmerer, E. Helmers, P. Hubner, G. Mascart, M. Milandri, F. Reinthaler, M. Zwakenberg, Sci. Total Environ. 225 (1999) 155.

[45] J. Vidmar, A. Martinčič, R. Milačič, J. Ščančar, Talanta 138 (2015) 1.

[46] R.F. Hill, W.J. Mayer, IEEE Trans. Nucl. Sci. 24 (1977) 2549.

[47] F. Zereini, B. Skerstupp, F. Alt, E. Helmers, H. Urban, Sci. Total Environ. 206 (1997) 137.

[48] M. Hawieńczyk, G. Bystrzejewska-Piotrowska, J. Kowalska, M. Asztemborska, Nukleonika 50 (2005)

[49] B.A. Lesniewska, J. Messerschmidt, N. Jakubowski, A. Hulanicki, Sci. Total Environ. 322 (2004) 95.

[50] P. Viñas, I. López-García, B. Merino-Meroño, M. Hernández-Córdoba, Appl. Organomet. Chem. 19 (2005) 930.

[51] R.A. Diaz-Bone, M. Raabe, S. Awißus, B. Keuter, B. Menzel, K. Küppers, R. Widmann, A.V. Hirner, J. Hazard. Mater. 189 (2011) 653.

[52] Y. Anan, M. Yoshida, S. Hasegawa, R. Katai, M. Tokumoto, L. Ouerdane, R. Łobiński, Y. Ogra, Metallomics 5 (2013) 1215.

[53] E. Rosenberg, Rev. Environ. Sci. Biotechnol. 8 (2009) 29.

[54] E. Trikas, G.A. Zachariadis, E. Rosenberg, Anal. Bioanal. Chem. 406 (2014) 3489.

[55] B.J. Kaplan, G.M. Andrus, W.W. Parish, J. Altern. Compl. Med. 10 (2004) 345.

[56] J.S. Thayer, Appl. Organomet. Chem. 16 (2002) 677.

[57] B.E. Lück, H. Mann, H. Melzer, L. Dunemann, J. Begerow, Nephrol. Dial. Transplant. 14 (1999) 2464.

[58] A.G. Schauss, Biol. Trace Elem. Res. 29 (1991) 267.

[59] N. Sugiyama, Y. Shikamori, J. Anal. Atomic Spectrom. 30 (2015) 2481.

[60] C.M. Tseng, D. Amouroux, I.D. Brindle, O.F.X. Donard, J. Environ. Monit. 2 (2000) 603.

[61] J. Szpunar, TrAC - Trends Anal. Chem. 19 (2000) 127.

[62] H. Chassaigne, V. Vacchina, R. Łobiński, TrAC - Trends Anal. Chem. 19 (2000) 300.

[63] H.R. Hansen, M. Jaspars, J. Feldmann, Analyst 129 (2004) 1058.

[64] R. Lobiński, J. Szpunar, Anal. Chim. Acta 400 (1999) 321.

[65] S. Rapsomanikis, O.F.X. Donard, J.H. Weber, Anal. Chem. 58 (1986) 35.

[66] K. Bierła, A. Riu, L. Debrauwer, D. Zalko, B. Bouyssiere, J. Szpunar, J. Anal. Atomic Spectrom. 25 (2010) 889.

[67] L. Ouerdane, S. Mari, P. Czernic, M. Lebrun, R. Łobiński, J. Anal. Atomic Spectrom. 21 (2006) 676.

[68] B. Krasnodbska-Ostrga, M. Sadowska, S. Ostrowska, Talanta 93 (2012) 326.

[69] L. Telgmann, C.A. Wehe, M. Birka, J. Künnemeyer, S. Nowak, M. Sperling, U. Karst, Environ. Sci. Technol. 46 (2012) 11929.

[70] R. Krüger, K. Braun, R. Pipkorn, W.D. Lehmann, J. Anal. Atomic Spectrom. 19 (2004) 852.

[71] V. Loreti, J. Bettmer, Anal. Bioanal. Chem. 379 (2004) 1050.

[72] C.L. Kahakachchi, D.A. Moore, Metallomics 2 (2010) 490.

[73] Q.Q. Wang, B.L. Huang, Z.W. Guan, L.M. Yang, B. Li, Fresen. J. Anal. Chem. 370 (2001) 1041

[74] R. Kautenburger, H.P. Beck, J. Chromatogr. A 1159 (2007) 75.

[75] R. Kautenburger, K. Nowotka, H.P. Beck, Anal. Bioanal. Chem. 384 (2006) 1416.

[76] J. Künnemeyer, L. Terborg, S. Nowak, A. Scheffer, L. Telgmann, F. Tokmak, A. Günsel, G. Wiesmüller, S. Reichelt, U. Karst, Anal. Chem. 80 (2008) 8163.

[77] M. Birka, C.A. Wehe, O. Hachmöller, M. Sperling, U. Karst, J. Chromatogr. A 1440 (2016) 105

[78] M. Birka, C.A. Wehe, L. Telgmann, M. Sperling, U. Karst, J. Chromatogr. A 1308 (2013) 125.

[79] M. Birka, K.S. Wentker, E. Lusmöller, B. Arheilger, C.A. Wehe, M. Sperling, R. Stadler, U. Karst, Anal. Chem. 87 (2015) 3321.

[80] C.S. Kesava Raju, A. Cossmer, H. Scharf, U. Panne, D. Lück, J. Anal. Atomic Spectrom. 25 (2010) 55.

[81] U. Lindner, J. Lingott, S. Richter, W. Jiang, N. Jakubowski, U. Panne, Anal. Bioanal. Chem. 407 (2015) 2415.

[82] L. Telgmann, H. Faber, S. Jahn, D. Melles, H. Simon, M. Sperling, U. Karst, J. Chromatogr. A 1240 (2012) 147.

[83] B. Krasnodębska-Ostrȩga, M. Sadowska, K. Piotrowska, M. Wojda, Talanta 112 (2013) 73.

[84] A.K. Das, M. Dutta, M.L. Cervera, M. de la Guardia, Microchem. J. 86 (2007) 2.

[85] U. Karlsson, A. Düker, S. Karlsson, J. Environ. Sci. Health - A Toxic/Hazardous Subst. Environ. Eng. 41 (2006) 1155.

[86] K.G. Scheckel, E. Lombi, S.A. Rock, M.J. McLaughlin, Environ. Sci. Technol. 38 (2004) 5095.

[87] Y.L. Chu, R.Y. Wang, S.J. Jiang, J. Chin. Chem. Soc. 59 (2012) 219.

[88] S. Szopa, R. Michalski, Spectrosc. (Santa Monica) 30 (2015). 
[89] G. Anderegg, E. Bottari, Helv. Chim. Acta 50 (1967) 2341.

[90] P.P. Coetzee, J.L. Fischer, M. Hu, Water SA 29 (2003) 17.

[91] L. Bencs, K. Ravindra, R. Van Grieken, Spectrochim. Acta - B Atom. Spectrosc. 58 (2003) 1723.

[92] V. Nischwitz, B. Michalke, A. Kettrup, J. Chromatogr. A 1016 (2003) 223.

[93] V. Nischwitz, B. Michalke, A. Kettrup, Anal. Chim. Acta 521 (2004) 87.
[94] A. Cobelo-García, Environ. Sci. Pollut. Res. 20 (2013) 2330.

[95] K. Lenz, G. Koellensperger, S. Hann, N. Weissenbacher, S.N. Mahnik, M. Fuerhacker, Chemosphere 69 (2007) 1765.

[96] P. Pinel-Raffaitin, C. Pécheyran, D. Amouroux, Atmos. Environ. 42 (2008) 7786.

[97] C.Y. Kuo, S.J. Jiang, J. Chromatogr. A 1181 (2008) 60.

[98] P. Krystek, R. Ritsema, J. Trace Elem. Med. Biol. 18 (2004) 9. 